\title{
THE ANALYSIS OF INCOME POVERTY IN WAD BANDA LOCALITY, NORTH KORDOFAN STATE
}

\author{
Dr. Mahgoub Emad Ahmed,
}

Agricultural Research Corporation

Mohammed Abdalla Teabin

Department of Agric. Economics, University of Zalingei

\author{
Dr. Mohammed Ahmed Osman Ibnouf \\ Prof. Abda Abdalla Imam \\ Department of Agric. Economics \\ Sudan University Of Science And Techonology
}

Doi: 10.19044/elp.v1no2a7 URL:http://dx.doi.org/10.19044/elp.v1no2a7

\begin{abstract}
This study aimed to analysis income poverty in Wad Banda Locality, North Kordofan State. Both primary and secondary data were used. Primary data were collected through field survey conducted on Sep. 2009 using questionnaire. The study used Foster, Greer, and Thorbecke index (FGT index) as main technique for measuring poverty. The study showed that income poverty was highly prevalent in study area. The study recommended that the most vulnerable (or poor) people need to be better targeted through capacity building programs in order to have significant positive impact on their status or to make the path out of poverty.
\end{abstract}

Keywords: Income Poverty in Wad Banda

\section{Introduction}

Poverty is a multi-dimension concept. Experts and academics have suggested many definitions over time. For example, poverty could be the lack of command over commodities in general; alternatively, it could be the lack of command over some basic goods (e.g., food and housing). More generally, poverty is the lack of capability to function in a given society. All these definitions point to poverty as a status in which a reasonable standard of living is not achieved. A synthesis of the various positions has been made by the World Bank, poverty is the lack of, or the inability to achieve, a socially acceptable standard of living (FAO, 2005, W.B, 2005). 
The most important question which arise, why we measure poverty? For answering this question there are four reasons to measure poverty. First, to keep the poor on the agenda; if poverty were not measured, it would be easy to forget the poor. Second, to be able to target interventions that aim to reduce or alleviate poverty. Third, to monitor and evaluate projects and policy interventions that is geared towards the poor. Fourth to evaluate the effectiveness of institutions whose goal is to help the poor. And finally, to help countries think clearly and systematically about how the position of the poor may be improved, (W.B, 2005).

\section{Problem Statement}

Over the past several decades, livelihoods in North Kordofan State were affected by frequent drought cycles. It is also suffers from extreme fluctuations in rainfall which generally vary from 150-450 mm/year. Severe climatic conditions and land mismanagement (overgrazing, over cropping, deforestation) have caused vegetation cover in North Kordofan State to become very poor and lowest many endemic species (woody, rangeland species) that were once dominant. Furthermore, there is a persistent threat associated with shifting sand as result of bordering the desert zone, (GEF, 2009). Faki et al (2009) expressed that food poverty in North Kordofan State is the highest among four States included in survey conducted 2008 besides Kassla, River Nile, and Northern state. Using income poverty from crops alone, the incidence, depth, and severity of food poverty were 99.5, 83.9, and 84.0 percent, respectively. These points raise some questions which need to be address to establish a complete picture of poverty situation in North Kordofan State:

1. What are the key indicators of incidence of poverty in Wad Banda Locality of North Kordofan State?

2. What are the main causes of poverty in Wad Banda Locality?

3. What needs to be done to improve people livelihood and reduce their poverty? And what policies need to be developed?

\section{The objective of the study}

The main objective of the study is to analysis Income Poverty in Wad Banda Locality, North Kordofan State.

The specific objectives are:

1. To Identify and describe poverty situation in the study area.

2. Identification and analysis causes of poverty in economic framework.

3. To suggest policies for poverty reduction.

\section{Hypotheses of study}

1. The majority of people in the study area are under poverty line. 
2. Illiteracy and drought are some causes of poverty.

3. The governmental programs which used to address poverty so far tend to excessively emphasize on symptom rather than attacking the roots causes of poverty.

\section{The research methodology}

Both primary and secondary data were used in this study. A questionnaire was used to collect primary data to assess key issues related to poverty in NKS. Hundred household heads were chosen through simplified random sampling.

The main analysis technique for the study was Foster, Greer, and Thorbecke index (FGT index) which include incidence of poverty; poverty gap; and severity of poverty. Poverty indicators for both income and consumption were calculated following Faki et al (2009) approach by using 2.6 as poverty line for NKS. Descriptive statistics, correlation, Lorenz Curve, and Gini Coefficient were also used in data analysis.

\section{Poverty measurement using income}

Using income for measuring poverty, findings of the study revealed that poverty was highly prevalence among people in study area. Income was decomposed into four categories, income from crops as denoted by $\left(\mathrm{Y}_{1}\right)$, income from crops plus livestock as denoted by $\left(\mathrm{Y}_{2}\right)$, income from $\left(\mathrm{Y}_{2}\right)$ plus income from off farm activities as denoted by $\left(\mathrm{Y}_{3}\right)$ and income from $\left(\mathrm{Y}_{3}\right)$ plus income from remittances as denoted by $\left(\mathrm{Y}_{4}\right)$. This decomposition methodology of income was taken from Faki et al (2009). Results of the study showed that the incidence of poverty was $100 \%$ with regards to income from crop production only $\left(\mathrm{Y}_{1}\right)$. The addition of income from livestock to income from crop production $\left(\mathrm{Y}_{2}\right)$ reduced incidence of poverty only from $100 \%$ to $99 \%$. Adding income from off-farm activities to income from $\mathrm{Y}_{2}$ $\left(\mathrm{Y}_{3}\right)$ reduced headcount index from $99 \%$ to $92 \%$. With regards to total income $\left(\mathrm{Y}_{4}\right)$ or when we added remittance to income from $\left(\mathrm{Y}_{3}\right)$, the incidence of poverty falls to $90 \%$ which considered relatively very high table (1). This result relatively near to Faki et al (2009) results for incidence of poverty for North Kordofan which was $99.5 \%, 98.1 \%, 81.5 \%$, and $81.3 \%$ for $\left(\mathrm{Y}_{1}\right),\left(\mathrm{Y}_{2}\right),\left(\mathrm{Y}_{3}\right)$ and $\left(\mathrm{Y}_{4}\right)$ respectively.

Poverty gap and severity were $83 \%$ and $71 \%$ respectively with regards to $\left(\mathrm{Y}_{1}\right), 72 \%$ and $58 \%$ respectively for $\left(\mathrm{Y}_{2}\right), 65 \%$ and $50 \%$ respectively for $\left(\mathrm{Y}_{3}\right)$ and $61 \%$ and $46 \%$ respectively for total income $\left(\mathrm{Y}_{4}\right)$. Faki et al (2009) resulted that poverty gap (depth of poverty) for North Kordofan State was $83.9 \%, 78.7 \%, 51.6 \%$ and $45.4 \%$ for $\left(\mathrm{Y}_{1}\right),\left(\mathrm{Y}_{2}\right),\left(\mathrm{Y}_{3}\right)$ and $\left(\mathrm{Y}_{4}\right)$ respectively, while poverty severity was $84.0 \%, 78.8 \%, 51.7 \%$ and $45.5 \%$ for $\left(\mathrm{Y}_{1}\right),\left(\mathrm{Y}_{2}\right),\left(\mathrm{Y}_{3}\right)$ and $\left(\mathrm{Y}_{4}\right)$ respectively. 
Table (1): Income poverty indicators

\begin{tabular}{|l|l|l|l|l|l|l|l|}
\hline income categories & $\mathrm{Y}_{1}$ & $\mathrm{Y}_{2}$ & $\mathrm{D}_{1}$ & $\mathrm{Y}_{3}$ & $\mathrm{D}_{2}$ & $\mathrm{Y}_{4}$ & $\mathrm{D}_{3}$ \\
\hline head count (incidence of poverty)\% & 100 & 99 & -1 & 92 & -7 & 90 & -2 \\
\hline poverty gap & 83 & 72 & -11 & 65 & -7 & 61 & -4 \\
\hline poverty severity & 71 & 58 & -13 & 50 & -8 & 46 & -4 \\
\hline income gap ratio & 83 & 73 & -1 & 70 & -3 & 67 & -3 \\
\hline mean income of poor & 45 & 70 & 25 & 78 & 8 & 85 & 7 \\
\hline mean income of no poor & 0 & 3.38 & 3.38 & 3.59 & 0.21 & 3.63 & 4 \\
\hline
\end{tabular}

Source: Calculated from the field survey data (2009).

Note: $\mathrm{Y}_{1}=$ income adult equivalent from crops a day, $\mathrm{Y}_{2}=$ income adult equivalent from crops + livestock a day, $\mathrm{Y}_{3}=$ income adult equivalent from crops + livestock + off farm activities a day, $\mathrm{Y}_{4}=$ total income per adult equivalent a day (income adult equivalent from crops + livestock + off farm activities a day + remittances). $\mathrm{D}_{1}, \mathrm{D}_{2}, \mathrm{D}_{3}$ and $\mathrm{D}_{4}$ change in poverty due to change in income.

\section{Income and consumption correlations}

Findings of the study revealed that income of households interviewed was positively highly correlated with education and consumption at 0.01 level of significance. While had no significant correlation with age, gender, family size, family size in adult equivalent, and property. This indicates that education is important factor in compacting poverty and improving living standards, table (2).

Table (2): Income correlations

\begin{tabular}{|l|l|l|}
\hline Variables & Pearson Correlation & Sig. (2-tailed) \\
\hline Age & 0.03 & 0.76 \\
\hline Gender & -0.16 & 0.10 \\
\hline Education & 0.25 & 0.01 \\
\hline Family size & -0.09 & 0.36 \\
\hline Family size in adult equivalent & -0.13 & 0.21 \\
\hline Property & -0.05 & 0.65 \\
\hline Total consumption & 0.98 & 0.00 \\
\hline
\end{tabular}

Source: Calculated from the field survey data (2009).

\section{Gini coefficient and inequality}

The Gini coefficient is usually defined mathematically based on the Lorenz curve. It is the ratio of the area that lies between the line of equality and the Lorenz curve. Results of the study showed that Income Gini coefficient was 0.47 , figure (1). Since 0 for Gini coefficient corresponding to complete equality, and 1 corresponding to complete inequality, the 
households income distribution come near to the middle which indicate moderate income distribution.

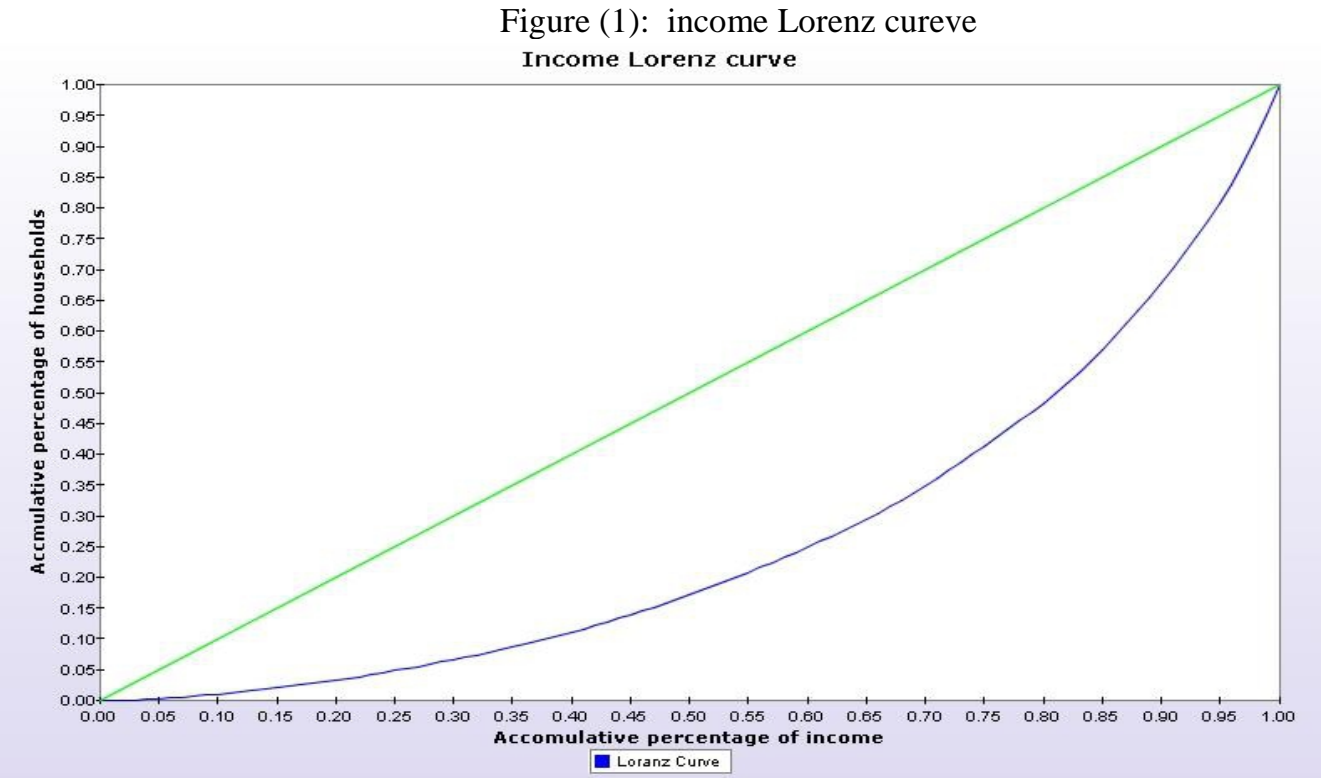

Source: Drived from the field survey data (2009).

\section{Recommendations}

1. Focusing on capacity building programs to help poor in gaining essential capabilities and skills which empower them to become effective economic agents.

2. Giving more attention on women development programs which enable them to contribute efficiently in improving living standards of their households.

3. Providing more and better basic services such as education, health, transportation and communications through focusing on improvement of infrastructures for these services.

\section{References:}

Faki Hamid, Eltahir Mohamed Nur, and Abdelaziz Abdelfattah. Poverty Assessment in Sudan IFAD Grant 961. Khartoum, 2009, 7-9, 11-15, 19-27, 51,63 .

FAO. Impacts of Policies on Poverty: The Definition of Poverty. Rome, 2005, 1-5.

Global Environment Facility (GEF). Implementing NAPA Priority Interventions to build Resilience in the Agriculture and Waters Sectors to the Adverse Impacts of Climate Change. Washington, 2009.

World Bank. Poverty manual, 2005. 